\title{
How do we perceive serendipity?
}

\author{
Quy Khuc \\ Draft version 1: 2022/03/01
}

\begin{abstract}
Remarks
This document is unpublished and not for circulation. It represents some preliminary and unpublished content of a chapter in the edited book titled A New Theory of Serendipity: Nature, Emergence and Mechanism, which will soon be published and distributed by De Gruyter Poland (Sciendo Imprint; part of Walter de Gruyter GmbH, Berlin, Germany).
\end{abstract}

This book chapter should be cited as follows:

Quy Khuc. (2022). How do we perceive serendipity?. In: QH Vuong. (Ed.) A New Theory of Serendipity: Nature, Emergence and Mechanism (pp. 13-40). Berlin, Germany: De Gruyter. 


\section{$\infty$}

In order to set a ground for the new hypotheses, theory, and conceptual framework of serendipity, the current chapter aims to review the research landscapes, definitions, types, influential factors, and processes of serendipity. First, bibliometric analyses of 2982 documents retrieved from the Web of Science database were employed to examine the intellectual and conceptual structures in the research field of serendipity. Three major research lines are found: 1) information-seeking behaviors, 2) serendipity in business and sciences, and 3) serendipity in recommender systems. Then, a narrative review of the most notable documents and studies was done to overview the serendipity's definitions, types, influential factors, and processes. Based on the review, we stipulate the literature gap in which the newly proposed hypotheses, theory, and conceptual framework will fit in. 


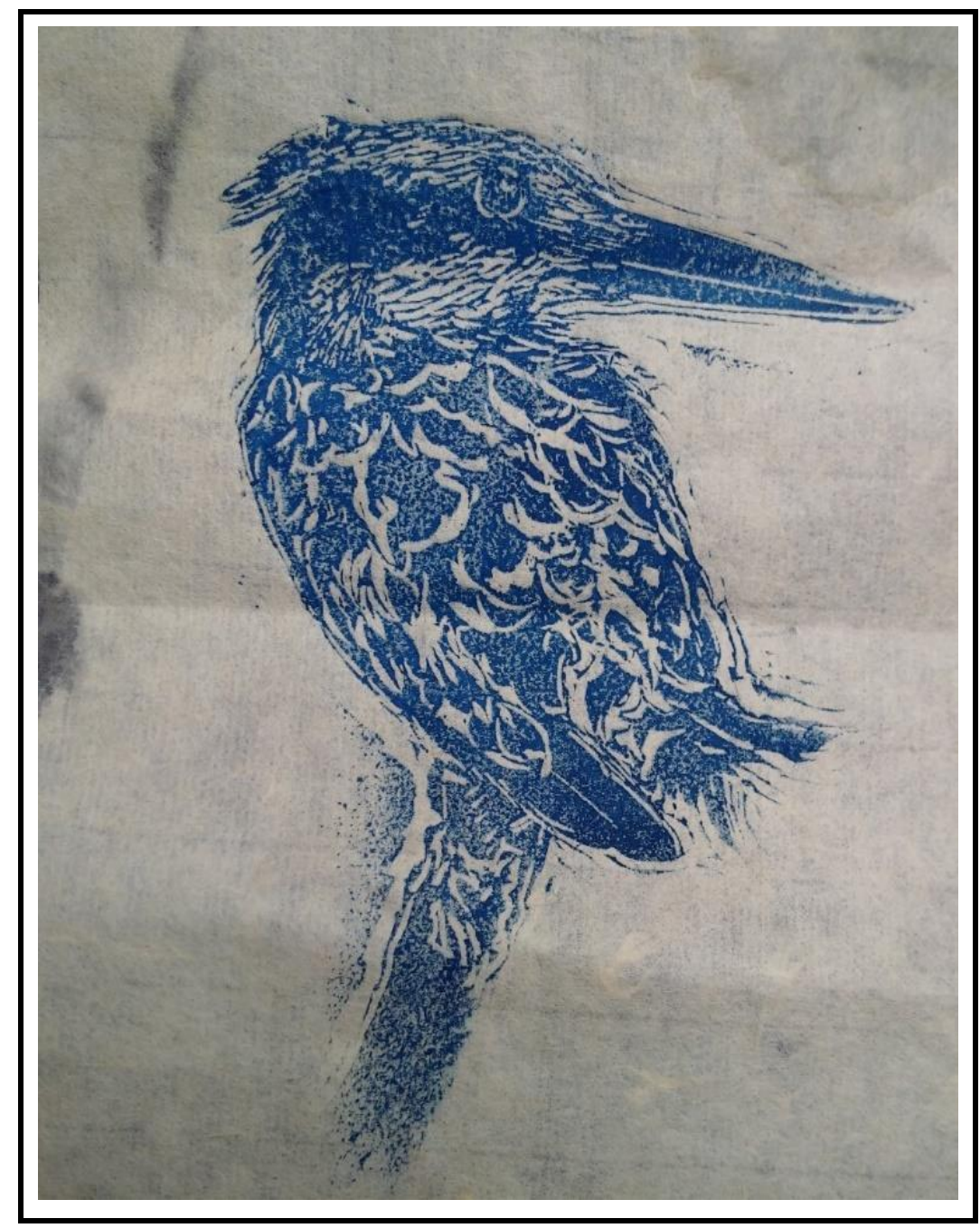

Kingfisher

(C)2017 Bui Quang Khiem 


\section{Book references}

Adam, D. (2021). How far will global population rise? Researchers can't agree. Nature, 597, 462-465.

Alleva, L. (2006). Taking time to savour the rewards of slow science. Nature, 443(7109), 271.

Andel, P. v. (1994). Anatomy of the unsought finding. Serendipity:

Origin, history, domains, traditions, appearances, patterns and programmability. The British Journal for the Philosophy of Science, 45(2), 631-648.

Anderson, W. A., Banerjee, U., Drennan, C. L., Elgin, S. C. R., Epstein, I. R., Handelsman, J., ... Warner, I. M. (2011). Changing the culture of science education at research universities. Science, 331(6014), 152-153.

Andrade, T. (2017). The gunpowder age: China, military innovation, and the rise of the West in world history. Princeton University Press.

André, P., Schraefel, M., Teevan, J., \& Dumais, S. T. (2009). Discovery is never by chance: designing for (un) serendipity. Proceedings of the Seventh ACM Conference on Creativity and Cognition, 305314.

Barber, B., \& Fox, R. C. (1958). The case of the floppy-eared rabbits: An instance of serendipity gained and serendipity lost. American Journal of Sociology, 64(2), 128-136.

Bates, S. (2017). Literature Listing. World Patent Information, 48, 29-41.

Bates, S. (2019). Literature Listing. World Patent Information, 57, 41-54.

Bates, S. (2020). Literature Listing. World Patent Information, 61, 101963.

Belfort, J. (2007). The Wolf of Wall Street. Bantam Books.

Bergström, A., Stringer, C., Hajdinjak, M., Scerri, E. M. L., \&

Skoglund, P. (2021). Origins of modern human ancestry.

Nature, 590, 229-237. 
Berkun, S. (2010). The Myths of Innovation. O'Reilly.

Birnbaum, J. (2022). Why video game makers see huge potential in Blockchain - and why problems loom for their new NFTs. Forbes.

Retrieved from (January 11, 2022)

https://www.forbes.com/sites/justinbirnbaum/2022/01/06/why

-video-game-makers-see-huge-potential-in-blockchain-andwhy-problems-loom-for-their-new-nfts/?sh=6abd10f043d7

Björneborn, L. (2008). Serendipity dimensions and users' information behaviour in the physical library interface. Information Research, 13(4), 370.

Braun, D. R., Aldeias, V., Archer, W., Arrowsmith, J. R., Baraki, N., Campisano, C. J., ... Reed, K. E. (2019). Earliest known Oldowan artifacts at >2.58 Ma from Ledi-Geraru, Ethiopia, highlight early technological diversity. Proceedings of the National Academy of Sciences, 116(24), 11712-11717.

Brown, S. (2005). Science, serendipity and the contemporary marketing condition. European Journal of Marketing, 39(11/12), 1229-1234.

Camus, A. (2013). The myth of Sisyphus. Penguin UK (Originally published in 1942).

Charlton, B. G., \& Walston, F. (2002). Individual case studies in clinical research. Journal of Evaluation in Clinical Practice, 4(2), 147-155.

Chase, K. (2003). Firearms: A global history to 1700. Cambridge University Press.

Chau, N. B., Hoang, V. Q., Phuong, L. V., Hoa, L. T., Ha, L. M., Giang, T. T. T., ... Toan, H. M. (2020). The 80-year development of Vietnam mathematical research: Preliminary insights from the SciMath database on mathematicians, their works and their networks. Technical Report No. VIASM-AISDL-20.02, 
presented at VIASM Scientific Council Meeting on November 13, 2020. Retrieved from (January 10, 2022) https://arxiv.org/abs/2011.09328

Chiến, B. N., \& Hoàng, V. Q. (2015). Bằng chứng cuộc sống: Suy ngẫm về phát triên bền vĩung Việt Nam. NXB Chính trị Quốc gia Sự Thật.

Choi, C. (2016). Ancient Chinese may have cultivated grass seeds 30,000 years ago. PNAS Journal Club. https://blog.pnas.org/2016/03/journal-club-ancient-chinesemay-have-cultivated-grass-seeds-30000-years-ago/

Clark, T. J. (2013). Picasso and truth: from Cubism to Guernica (Vol. 56). Princeton University Press.

Copeland, S. (2019). On serendipity in science: discovery at the intersection of chance and wisdom. Synthese, 196(6), 23852406.

Cunha, M. P. (2005). Serendipity: why some organizations are luckier than others. FEUNL Working Paper Series, 472.

Cunha, M. P. e., Clegg, S. R., \& Mendonça, S. (2010). On serendipity and organizing. European Management Journal, 28(5), 319-330.

Curtin, N. J. (2020). The development of Rucaparib/Rubraca ${ }^{\circledR}$ : A story of the synergy between science and serendipity. Cancers, 12(3), 564.

Darwin, C. (2003). On the origin of species (D. Knight, Ed. Reprint ed.). Routledge.

Dasgupta, S. (2019). The complexity of creativity: Les Demoiselles D'Avignon as a cognitive-historical laboratory. Creativity Research Journal, 31(4), 377-394.

De Rond, M. (2014). The structure of serendipity. Culture and Organization, 20(5), 342-358. 
Delcourt, M. A. (2003). Five ingredients for success: two case studies of advocacy at the state level. Gifted Child Quarterly, 47(1), 2637.

Denrell, J., Fang, C., \& Winter, S. G. (2003). The economics of strategic opportunity. Strategic Management Journal, 24(10), 977-990.

Dew, N. (2009). Serendipity in entrepreneurship. Organization Studies, 30(7), 735-753.

Diamond, J. M. (2011). Collapse: how societies choose to fail or survive. Penguin Books.

Diaz de Chumaceiro, C. L. (2004). Serendipity and pseudoserendipity in career paths of successful women: Orchestra conductors. Creativity Research Journal, 16(2-3), 345-356.

Đỗ, T. L. (2015). Nhũung cây thuốc và vị thuốc Việt Nam (19 ed.). NXB Hông Đức.

Eisenhardt, K. M. (1989). Building theories from case study research. Academy of Management Review, 14(4), 532-550.

Ekins, S., Diaz, N., Chung, J., Mathews, P., \& McMurtray, A. (2017). Enabling anyone to translate clinically relevant ideas to therapies. Pharmaceutical Research, 34(1), 1-6.

Fine, G. A., \& Deegan, J. G. (1996). Three principles of Serendip: insight, chance, and discovery in qualitative research. International Journal of Qualitative Studies in Education, 9(4), 434-447.

Fink, T. M. A., Reeves, M., Palma, R., \& Farr, R. S. (2017). Serendipity and strategy in rapid innovation. Nature Communications, 8 , 2002.

Fisberg, M., \& Machado, R. (2015). History of yogurt and current patterns of consumption. Nutrition Reviews, 73(suppl_1), 4-7.

Forbes. (2021). Howard Schultz. Forbes. Retrieved from (January 11, 2022) https://www.forbes.com/profile/howard-schultz/ 
Foster, A., \& Ford, N. (2003). Serendipity and information seeking: an empirical study. Journal of Documentation, 59(3), 321-340.

Gaglio, C. M., \& Katz, J. A. (2001). The psychological basis of opportunity identification: Entrepreneurial alertness. Small Business Economics, 16(2), 95-111.

Ge, M., Delgado-Battenfeld, C., \& Jannach, D. (2010). Beyond accuracy: evaluating recommender systems by coverage and serendipity. Proceedings of the Fourth ACM Conference on Recommender Systems, 257-260.

Gilbert, E. (2016). Big magic: creative living beyond fear. Riverhead Books.

Ginsburg, A. S., \& Klugman, K. P. (2020). COVID-19 pneumonia and the appropriate use of antibiotics. The Lancet Global Health, 8(12), e1453-e1454.

Gothard, K. M. (2020). Multidimensional processing in the amygdala. Nature Reviews Neuroscience, 21(10), 565-575.

Gowlett, J. A. J. (2016). The discovery of fire by humans: a long and convoluted process. Philosophical Transactions of the Royal Society B: Biological Sciences, 371(1696).

Grivtsova, L. Y., Falaleeva, N. A., \& Tupitsyn, N. N. (2021). Azoximer Bromide: mystery, serendipity, and promise. Frontiers in Oncology, 11, 699546.

Haas, B. D. (2021). What my retraction taught me. Nature, 589, 331.

Hart, R. A. (2013). Children's participation: the theory and practice of involving young citizens in community development and environmental care. Routledge.

Harvey, F. (2021). Climate experts warn world leaders 1.5C is 'real science', not just talking point. The Guardian. Retrieved from (January 11, 2022)

https://www.theguardian.com/environment/2021/oct/30/clima 
te-experts-warn-world-leaders-15c-is-real-science-not-justtalking-point

Herlocker, J. L., Konstan, J. A., Terveen, L. G., \& Riedl, J. T. (2004).

Evaluating collaborative filtering recommender systems. ACM Transactions on Information Systems, 22(1), 5-53.

Holman, L., Head, M. L., Lanfear, R., \& Jennions, M. D. (2015). Evidence of experimental bias in the life sciences: why we need blind data recording. PLoS Biology, 13(7), e1002190.

Huynh, T. L. D. (2020). Does culture matter social distancing under the COVID-19 pandemic? Safety Science, 130, 104872.

Iborra, L. (n.d.). Penrose Triangle. The Noun Project. Retrieved from (March 10, 2021)

https://thenounproject.com/search/?creator=2129742\&q=Penro se\& $\mathrm{i}=881121$

International Dairy Foods Association. (2021). History of cheese.

International Dairy Foods Association. Retrieved from https://www.idfa.org/news-views/media-kits/cheese/historyof-cheese (accessed on: January 11, 2022)

Jiang, S., Li, Y., Lu, Q., Hong, Y., Guan, D., Xiong, Y., \& Wang, S. (2021). Policy assessments for the carbon emission flows and sustainability of Bitcoin blockchain operation in China. Nature Communications, 12, 1938.

Kata, A. (2010). A postmodern Pandora's box: Anti-vaccination misinformation on the Internet. Vaccine, 28(7), 1709-1716.

Kames, J., Holcomb, D. D., Kimchi, O., DiCuccio, M., HamasakiKatagiri, N., Wang, T., ... Kimchi-Sarfaty, C. (2020). Sequence analysis of SARS-CoV-2 genome reveals features important for vaccine design. Scientific Reports, 10(1), 15643.

Kellner, A., \& Robertson, T. (1954). Selective necrosis of cardiac and skeletal muscle induced experimentally by means of 
proteolytic enzyme solutions given intravenously. The Journal of Experimental Medicine, 99(4), 387-404.

Kellner, A., Robertson, T., \& Mott, H. (1951). Blood coagulation defect induced in rabbits by papain solutions injected intravenously. Federation Proceedings, 10(1).

Kolbert, E. (2014). The sixth extinction: an unnatural history (First edition ed.). Henry Holt and Company.

Kotkov, D., Wang, S., \& Veijalainen, J. (2016). A survey of serendipity in recommender systems. Knowledge-based systems, 111, 180192.

Krause, M. J., \& Tolaymat, T. (2018). Quantification of energy and carbon costs for mining cryptocurrencies. Nature Sustainability, 1(11), 711-718.

La, V.-P., \& Vuong, Q.-H. (2019). bayesvl: Visually learning the graphical structure of Bayesian networks and performing MCMC with 'Stan'. The Comprehensive R Archive Network (CRAN).

Lawley, J., \& Tompkins, P. (2011). Maximising serendipity: The art of recognising and fostering unexpected potential - A systemic approach to change. The Clean Collection. Retrieved from https://cleanlanguage.co.uk/articles/articles/224/1/Maximising -Serendipity/Page1.html (accessed on: December 31, 2021)

Le, T.-T., Nguyen, M.-H., \& Vuong, Q.-H. (2021). Misinformation and the mindsponge mechanism of trust. OSF Preprints. https://osf.io/m9sj3

Lee, W. E. (2016). Waging war: conflict, culture, and innovation in world history. Oxford University Press.

Levy, O., Beechler, S., Taylor, S., \& Boyacigiller, N. A. (2007). What we talk about when we talk about 'global mindset': 
managerial cognition in multinational corporations. Journal of International Business Studies, 38(2), 231-258.

Makri, S., \& Blandford, A. (2012). Coming across information serendipitously-Part 1: A process model. Journal of Documentation, 68(5), 684-705.

Makri, S., Blandford, A., Woods, M., Sharples, S., \& Maxwell, D. (2014). "Making my own luck": serendipity strategies and how to support them in digital information environments. Journal of the Association for Information Science and Technology, 65(11), 2179-2194.

Maslow, A. H. (1943). A theory of human motivation. Psychological Review, 50(4), 370-396.

Maslow, A. H. (1981). Motivation and personality. Prabhat Prakashan.

McBirnie, A. (2008). Seeking serendipity: the paradox of control. Aslib Proceedings, 60(6), 600-618.

McCay-Peet, L., \& Toms, E. G. (2010). The process of serendipity in knowledge work. Proceedings of the Third Symposium on Information Interaction in Context.

McCay-Peet, L., \& Toms, E. G. (2015). Investigating serendipity: how it unfolds and what may influence it. Journal of the Association for Information Science and Technology, 66(7), 1463-1476.

Mendonça, S., Cunha, M., \& Clegg, S. R. (2008). Unsought innovation: serendipity in organizations. Entrepreneurship and Innovation - Organizations, Institutions, Systems and Regions Conference, Copenhagen.

Merton, R. K. (1948). The bearing of empirical research upon the development of social theory. American Sociological Review, 13(5), 505-515.

Merton, R. K. (1968). Social theory and social structure. Free Press. 
Merton, R. K., \& Barber, E. (2004). The travels and adventures of serendipity: a study in sociological semantics and the sociology of science. Princeton University Press.

Miller, D. (2010). The book whisperer: Awakening the Inner Reader in Every Child. John Wiley \& Sons.

Monument to Ernest Solvay. (1932). Nature, 130, 657.

Munafò, M. R., Nosek, B. A., Bishop, D. V. M., Button, K. S., Chambers, C. D., Percie du Sert, N., ... Ioannidis, J. P. A. (2017). A manifesto for reproducible science. Nature Human Behaviour, 1, 0021.

Napier, N., \& Vuong, Q. H. (2013). Serendipity as a strategic advantage? In T. Wilkinson (Ed.), Strategic management in the 21st century (pp. 175-199). Praeger/ABC-Clio.

Napier, N. K. (2010). Insight: encouraging Aha! moments for organizational success. Praeger.

Napier, N. K., Bahnson, P. R., Glen, R., Maille, C. J., Smith, K., \& White, H. (2009). When "Aha moments" make all the difference. Journal of Management Inquiry, 18(1), 64-76.

Napier, N. K., \& Nilsson, M. (2008). The creative discipline: mastering the art and science of innovation. Praeger.

Napoli, R. (2021). The NFT metaverse: building a blockchain world. Forbes. Retrieved from (accessed on: January 11, 2022) https://www.forbes.com/sites/forbestechcouncil/2021/12/27/th e-nft-metaverse-building-a-blockchainworld/?sh=4c5bab5a531c

National Coffee Association USA. (2021). The history of coffee. National Coffee Association USA. Retrieved from (December 26, 2021) https://www.ncausa.org/about-coffee/history-of-coffee 
Nguyen, M.-H. (2021). Subjective spheres of influence: A perceptual system beyond mindsponge. PhilArchive.

https://philarchive.org/rec/NGUSSO

Nguyen, M.-H., \& Le, T.-T. (2021). Information particle. OSF

Preprints. https://osf.io/fgjpz

Nguyen, M.-H., Le, T.-T., \& Khuc, Q. (2021). Bayesian Mindsponge

Framework. Scholarly Community Encyclopedia.

https://encyclopedia.pub/13852

Nguyen, M.-H., \& Vuong, Q.-H. (2021). Evaluation of the Aichi

Biodiversity Targets: The international collaboration trilemma in interdisciplinary research. Pacific Conservation Biology.

Online Early.

Nguyen, M.-H., Le, T.-T., Nguyen, H.-K. T., Ho, M.-T., Nguyen, H. T. T., \& Vuong, Q.-H. (2021). Alice in Suicideland: exploring the suicidal ideation mechanism through the sense of connectedness and help-seeking behaviors. International Journal of Environmental Research and Public Health, 18(7), 3681.

Nguyen, M.-H., Nguyen, H. T. T., Le, T.-T., Luong, A.-P., \& Vuong, Q.-H. (2021). Gender issues in family business research: A bibliometric scoping review. Journal of Asian Business and Economic Studies, ahead-of-print.

Nguyen, M.-H., Pham, T.-H., Ho, M.-T., Nguyen, H. T. T., \& Vuong, Q.-H. (2021). On the social and conceptual structure of the 50year research landscape in entrepreneurial finance. $S N$ Business E Economics, 1, 2.

Nguyen, H.-K. T., Nguyen, T.-H. T., Ho, M.-T., Ho, M.-T., \& Vuong, Q.-H. (2019). Scientific publishing: the point of no return. In Q. H. Vuong \& T. Trung (Eds.), The Vietnamese Social Sciences at a Fork in the Road (pp. 143-162). De Gruyter. 
Pálsdóttir, Á. (2011). Opportunistic discovery of information by elderly Icelanders and their relatives. Information Research, 16(3), 485.

Perianes-Rodriguez, A., Waltman, L., \& Van Eck, N. J. (2016).

Constructing bibliometric networks: A comparison between full and fractional counting. Journal of Informetrics, 10(4), 11781195.

Pham, H.-H., \& Ho, T.-T.-H. (2020). Toward a 'new normal' with elearning in Vietnamese higher education during the post COVID-19 pandemic. Higher Education Research $\mathcal{E}$ Development, 39(7), 1327-1331.

Pickering, A. (1992). Science as practice and culture (A. Pickering, Ed.). University of Chicago Press.

Popova, M. (2020). David Whyte on vulnerability, presence, and how we enlarge ourselves by surrendering to the uncontrollable.

Brainpickings. Retrieved from (January 03, 2022) https://www.brainpickings.org/2016/04/11/david-whytevulnerability/

Robinson, A. (2020). The archaeology of Armageddon. Nature, 578(7796), 510-512.

Roberts, R. M. (1989). Serendipity: accidental discoveries in science. Wiley.

Rogers, J. A. (1972). Darwinism and Social Darwinism. Journal of the History of Ideas, 33(2), 265.

Rosenau, M. J. (1935). Serendipity. Journal of Bacteriology, 29(2), 91-98.

Rubin, V. L., Burkell, J., \& Quan-Haase, A. (2011). Facets of serendipity in everyday chance encounters: a grounded theory approach to blog analysis. Information Research, 16(3), 488. 
Sampat, B. N. (2012). Mission-oriented biomedical research at the

NIH. Research Policy, 41(10), 1729-1741.

Satia, P. (2018). War drove 18th-century Industrial Revolution in Great

Britain. Stanford News. Retrieved from (December 25, 2021)

https://news.stanford.edu/2018/05/03/war-drove-18th-centuryindustrial-revolution-great-britain/

Satia, P. (2019). Empire of guns: the violent making of the Industrial

Revolution. Stanford University Press.

Schell, D., Wang, M., \& Huynh, T. L. D. (2020). This time is indeed different: A study on global market reactions to public health crisis. Journal of Behavioral and Experimental Finance, 27, 100349.

Sethna, Z. (2017). Editorial. Journal of Research in Marketing and Entrepreneurship, 19(2), 201-206.

Shea, J. J., \& Sisk, M. L. (2010). Complex projectile technology and Homo sapiens dispersal into western Eurasia.

PaleoAnthropology, 2010, 100-122.

Sheng, Z. M., Chertow, D. S., Ambroggio, X., McCall, S., Przygodzki,

R. M., Cunningham, R. E., ... Taubenberger, J. K. (2011). Autopsy series of 68 cases dying before and during the 1918 influenza pandemic peak. Proceedings of the National Academy of Sciences, 108(39), 16416-16421.

Spencer, H. (2020). The principles of biology: Volume 1. Outlook Verlag. Stahl, M., \& Baier, S. (2015). How many molecules does it take to tell a story? Case studies, language, and an epistemic view of medicinal chemistry. ChemMedChem, 10(6), 949-956.

Steele, C. M. (1988). The psychology of self-affirmation: Sustaining the integrity of the self. In L. Berkowitz (Ed.), Advances in experimental social psychology (Vol. 21, pp. 261-302). Elsevier.

Stengers, I., \& Muecke, S. (2018). Another science is possible: A manifesto for slow science. John Wiley \& Sons. 
Stringer, C., Pachitariu, M., Steinmetz, N., Reddy, C. B., Carandini, M., \& Harris, K. D. (2019). Spontaneous behaviors drive multidimensional, brainwide activity. Science, 364(6437), eaav7893.

Thagard, P., \& Croft, D. (1999). Scientific discovery and technological innovation: Ulcers, dinosaur extinction, and the programming language JAVA. In L. Magnani, N. J. Nersessian, \& P. Thagard (Eds.), Model-based reasoning in scientific discovery (pp. 125-137). Kluwer Academic/Plenum Publishers.

Thanh, V. (2021). Vietnam PM calls for climate justice at COP26.

VNExpress International. Retrieved from (December 31, 2021) https://e.vnexpress.net/news/news/vietnam-pm-calls-forclimate-justice-at-cop26-4380258.html

Thiem, L.-V. (1949). Über das Umkehrproblem der

Wertverteilungslehre. Commentarii Mathematici Helvetici, 23(1), 26-49.

Thiem, L.-V. (1950). Sur un problème d'inversion dans la théorie des fonctions méromorphes. Annales scientifiques de l'É.NS, 3e(67), 51-98.

Thomas, L. (1956). Reversible collapse of rabbit ears after intravenous papain, and prevention of recovery by cortisone. The Journal of Experimental Medicine, 104(2), 245.

Tollefson, J. (2021). Top climate scientists are sceptical that nations will rein in global warming. Nature, 599, 22-24.

Toms, E. G. (2000). Understanding and facilitating the browsing of electronic text. International Journal of Human-Computer Studies, 52(3), 423-452.

Tuy, H. (1968). On linear inequalities. (English. Russian original). Soviet Mathematics. Doklady, 9, 366-369. 
Tuy, H. (1986). A General Deterministic Approach to Global

Optimization VIA D.C. Programming. In J. B. Hiriart-Urruty (Ed.), North-Holland Mathematics Studies (Vol. 129, pp. 273303). North-Holland.

Tzu, S. (2021). The art of war. Vintage.

United Nations. (2021). Secretary-General calls latest IPCC Climate Report 'code red for humanity', stressing 'irrefutable' evidence of human influence. United Nations Meetings Coverage and Press Releases. Retrieved from (December 26, 2021) https://www.un.org/press/en/2021/sgsm20847.doc.htm

Uzzell, D. (1999). Education for environmental action in the community: New roles and relationships. Cambridge Journal of Education, 29(3), 397-413.

Van Eck, N. J., \& Waltman, L. (2014). Visualizing bibliometric networks. In Measuring scholarly impact (pp. 285-320). Springer.

Van Kleeck, A., Stahl, S. A., \& Bauer, E. B. (2003). On reading books to children: parents and teachers. Routledge.

Vietnam Government. (2010). Decision No. 1483/QD-TTg dated August 17, 2010, of the Prime Minister approving the national key program on mathematics development in the 2010-2020 period. Viet Nam Government Portal. Retrieved from (March 11, 2021).

Von Clausewitz, C. (2008). On war. Princeton University Press.

Vuong, Q. H. (2015). Be rich or don't be sick: estimating Vietnamese patients' risk of falling into destitution. SpringerPlus, 4(1), 529.

Vuong, Q.-H. (2018). The (ir)rational consideration of the cost of science in transition economies. Nature Human Behaviour, 2, 5.

Vuong, Q.-H. (2019). Breaking barriers in publishing demands a proactive attitude. Nature Human Behaviour, 3, 1034. 
Vuong, Q.-H. (2020a). From children's literature to sustainability science, and young scientists for a more sustainable Earth. Journal of Sustainability Education, 24(3), 1-12.

http://www.susted.com/wordpress/content/from-childrensliterature-to-sustainability-science-and-young-scientists-for-amore-sustainable-earth_2020_12/

Vuong, Q.-H. (2020b). Reform retractions to make them more transparent. Nature, 582, 149.

Vuong, Q.-H. (2021a). The semiconducting principle of monetary and environmental values exchange. Economics and Business Letters, 10(3), 284-290.

Vuong, Q.-H. (2021b). Western monopoly of climate science is creating an eco-deficit culture. Economy, Land $\mathcal{E}$ Climate Insight. https://elc-insight.org/western-monopoly-of-climatescience-is-creating-an-eco-deficit-culture/

Vuong, Q.-H., La, V.-P., Vuong, T.-T., Ho, M.-T., Nguyen, H.-K. T., Nguyen, V.-H., ... Ho, M.-T. (2018). An open database of productivity in Vietnam's social sciences and humanities for public use. Scientific Data, 5, 180188.

Vuong, Q.-H., Bui, Q.-K., La, V.-P., Vuong, T.-T., Nguyen, V.-H. T., Ho, M.-T., ... Ho, M.-T. (2018). Cultural additivity: behavioural insights from the interaction of Confucianism, Buddhism and Taoism in folktales. Palgrave Communications, 4, 143.

Vuong, Q.-H., Bui, Q.-K., La, V.-P., Vuong, T.-T., Ho, M.-T., Nguyen, H.-K. T., ... Ho, M.-T. (2019). Cultural evolution in Vietnam's early 20th century: a Bayesian networks analysis of Hanoi Franco-Chinese house designs. Social Sciences \& Humanities Open, 1(1), 100001. 
Vuong, Q.-H., La, V.-P., Nguyen, M.-H., Ho, M.-T., Tran, T., \& Ho, M.-T. (2020). Bayesian analysis for social data: a step-by-step protocol and interpretation. MethodsX, 7, 100924.

Vuong, Q.-H., Ho, M.-T., Nguyen, H.-K. T., Vuong, T.-T., Tran, T., Hoang, K.-L., ... La, V.-P. (2020). On how religions could accidentally incite lies and violence: folktales as a cultural transmitter. Palgrave Communications, 6, 82.

Vuong, Q.-H., Le, T.-T., La, V.-P., Nguyen, T. T. H., Ho, M.-T., Khuc, Q., \& Nguyen, M.-H. (2022). Covid-19 vaccines production and societal immunization under the serendipitymindsponge-3D knowledge management theory and conceptual framework. Humanities and Social Sciences Communications, 9, 22.

Vuong, Q.-H., \& Napier, N. K. (2015). Acculturation and global mindsponge: an emerging market perspective. International Journal of Intercultural Relations, 49, 354-367.

Vuong, Q.-H., Nguyen, M.-H., \& Le, T.-T. (2021a). Home scholarly culture, book selection reason, and academic performance: Pathways to book reading interest among secondary school students. European Journal of Investigation in Health, Psychology and Education, 11(2), 468-495.

Vuong, Q.-H., Nguyen, M.-H., \& Le, T.-T. (2021b). A mindsponge-based investigation into the psycho-religious mechanism behind suicide attacks. De Gruyter / Sciendo.

Vuong, Q. H. (2020). The rise of preprints and their value in social sciences and humanities. Science Editing, 7(1), 70-72.

Vuong, Q. H., \& Napier, N. K. (2014). Making creativity: the value of multiple filters in the innovation process. International Journal of Transitions and Innovation Systems, 3(4), 294-327.

Wallas, G. (1926). The Art of Thought. Jonathan Cape. 
Wang, C., Lu, H., Zhang, J., He, K., \& Huan, X. (2016). Macro-process of past plant subsistence from the Upper Paleolithic to Middle Neolithic in China: a quantitative analysis of multiarchaeobotanical data. PLoS One, 11(2), e0148136.

Watson, P. (2007). Ideas: a history of thought and invention, from fire to Freud. HarperPerennial.

Weiss, E., Kislev, M. E., Simchoni, O., \& Nadel, D. (2004). Smallgrained wild grasses as staple food at the 23000 -year-old site of Ohalo II, Israel. Economic Botany, 58, S125-S134.

Williams, E. N., Soeprapto, E., Like, K., Touradji, P., Hess, S., \& Hill, C. E. (1998). Perceptions of serendipity: career paths of prominent academic women in counseling psychology. Journal of Counseling Psychology, 45(4), 379.

Yaqub, O. (2018). Serendipity: towards a taxonomy and a theory. Research Policy, 47(1), 169-179.

Zhang, Y. C., Séaghdha, D. Ó., Quercia, D., \& Jambor, T. (2012).

Auralist: introducing serendipity into music recommendation. Proceedings of the Fifth ACM International Conference on Web Search and Data Mining, 13-22.

Zupic, I., \& Čater, T. (2015). Bibliometric methods in management and organization. Organizational Research Methods, 18(3), 429472. 